\title{
(6) OPEN ACCESS \\ Recall, appeal and willingness to try cigarettes with flavour capsules: assessing the impact of a tobacco product innovation among early adolescents
}

\author{
Erika N Abad-Vivero, ${ }^{1}$ James F Thrasher, ${ }^{1,2}$ Edna Arillo-Santillán, ${ }^{1}$ \\ Rosaura Pérez-Hernández, ${ }_{1}^{1}$ Inti Barrientos-Gutíerrez, ${ }^{1}$ Christy Kollath-Cattano, ${ }^{3}$ \\ Raúl Mejía, ${ }^{4}$ James D Sargent ${ }^{5}$
}

- Additional material is published online only. To view please visit the journal online (http://dx.doi.org/10.1136/ tobaccocontrol-2015-052805).

${ }^{1}$ Department of Tobacco Research, Center for Population Health Research, National Institute of Public Health, Cuernavaca, Morelos, México ${ }^{2}$ Department of Health Promotion, Education \& Behavior, Arnold School of Public Health, University of South Carolina, Columbia, South Carolina, USA

${ }^{3}$ School of Education, Health and Human Performance, College of Charleston, Charleston, South Carolina, USA

${ }^{4}$ Salud, Economía y Salud, Centro de Estudios de Estado y Sociedad (CEDES), Buenos

Aires, Argentina

${ }^{5}$ Norris Cotton Cancer Center, Geisel School of Medicine, Dartmouth College, Hanover, New Hampshire, USA

\section{Correspondence to} Dr James F Thrasher, Department of Health Promotion, Education \& Behavior, 915 Greene Street, Discovery I, University of South Carolina, Columbia, SC 29208, USA

thrasher@mailbox.sc.edu

Received 2 November 2015 Accepted 15 March 2016 Published Online First 8 April 2016

\author{
ABSTRACT \\ Background Use of flavour capsule varieties (FCVs) of \\ cigarettes has rapidly increased in many countries. \\ Adolescents are attracted to flavours; yet, surprisingly, no \\ quantitative study has explored adolescents' perceptions \\ of these products.
}

Objective To characterise the appeal of FCVs for young adolescents in Mexico.

Methods In 2015, surveys were conducted with a representative sample of Mexican middle school students ( $n=10$ 124; ages 11-16 years; mean 12.4 years).

Students viewed and rated packs for FCVs and non-FCVs from major brands (Marlboro, Camel, Pall Mall), with brand names removed. For each pack, students were asked to write the brand name (ie, brand recall), to evaluate pack attractiveness, and to indicate the pack they were most interested in trying (including a 'none' option). Logistic generalised estimating equation (GEE) models regressed brand recall, pack attractiveness and interest in trying on brand and FCV (yes vs no), controlling for sociodemographics and smoking risk factors.

Results Marlboro regular, Camel regular, Camel light and Pall Mall FCVs were most often recalled (25\%, $17 \%, 9 \%, 8 \%)$. Packs for Pall Mall FCVs and Camel FCVs were most often rated as very attractive $(13 \%, 9 \%$, respectively) and of interest for trial $(22 \%, 13 \%)$ along with Marlboro regular (14\%). In GEE models, FCVs were independently associated with greater attractiveness (adjusted OR (AOR)=1.83, 95\% Cl 1.72 to 1.94) and interest in trying ( $A O R=1.74,95 \% \mathrm{Cl} 1.54$ to 1.96). Perceived pack attractiveness was also independently associated with greater interest in trying $(A O R=5.63$, $95 \%$ Cl 4.74 to 6.68 ).

Conclusions FCVs appear to be generating even greater appeal among young adolescents than established non-FCVs in dominant brand families.

\section{INTRODUCTION}

Recent tobacco industry reports ${ }^{1-7}$ emphasise the explosive growth of the cigarette market for flavour capsule varieties (FCVs), which contain a capsule embedded in the filter that consumers crush to release a liquid that flavours the smoke. While independent research on cigarette FCVs is limited, ${ }^{8} 9$ it suggests that FCVs may promote adolescent smoking. This is a matter of particular concern given the potential appeal of flavours and cigarette design innovations for youth. ${ }^{8}{ }^{10-14}$ This study aims to provide the first quantitative data on adolescents' perceptions, use and willingness to try FCV cigarettes.

Cigarette FCVs are available in most markets ${ }^{4}$ and represent a novel industry strategy to add value to both premium and, in some countries like Mexico, discount brands by reinforcing perceptions of distinctiveness and quality. ${ }^{7}{ }^{15}$ FCVs are sold in cigarettes that contain both regular and flavoured tobacco, ${ }^{4}$ with some FCVs including two differently flavoured capsules in the same filter. Menthol $^{15}$ and menthol-related flavours (eg, spearmint, lemon mint, apple mint, strawberry mint ${ }^{16}$ are the most typical flavours. In double capsule varieties, one flavour capsule typically contains mint-related flavours and the other a non-menthol fruit flavour. The menthol in flavour capsules most likely works like menthol-flavoured tobacco, reducing the harshness of the smoke and potentially promoting misperceptions of reduced harm compared with non-flavoured cigarettes. ${ }^{9} 1012$

The two published studies of FCVs suggest their appeal for youth. Focus groups with Scottish females aged 12-24 years who were non-smokers or occasional smokers found positive evaluations of FCVs, such as perceiving them as 'cleaner', 'fresher', with a more pleasant taste than menthol tobacco cigarettes, as well as perceiving them as less harmful than standard cigarettes. ${ }^{8}$ Similarly, adult smokers perceive a range of benefits to FCVs relative to other brand varieties, including stylishness, taste and relatively lower harm, ${ }^{9}$ all of which may appeal to youth. Indeed, preference for FCVs is much higher among young adult smokers than among older adult smokers in Australia and the USA. ${ }^{9}$

\section{Study context}

In 2011, Marlboro introduced the first FCVs in Mexico, with Camel and Pall Mall following in the next year. ${ }^{17}$ Tobacco marketing in Mexico is mostly restricted to retail environments, ${ }^{18}$ and surveillance of retail environments in major Mexican cities during 2013 found 3 FCVs for Marlboro, 5 for Camel and 16 for Pall Mall. ${ }^{19}$ The rapid growth of the FCV market segment in Mexico has been remarkable, reaching $12 \%$ of all cigarette sales by 2014. ${ }^{17}$ The vast majority of adult Mexican smokers who prefer FCVs smoke Pall Mall (78\%), which is the only international brand priced at 'discount' levels, representing what appears to be an industry response to recent tax 
increases. $^{20} 21$ Compared with adult smokers of regularflavoured, premium-priced cigarettes, Mexican smokers who prefer Pall Mall FCVs perceive their brand variety as even smoother, lighter tasting and less harmful compared with other cigarette varieties. ${ }^{9}$

In this study, we assessed adolescents' perceptions of cigarette packaging because tobacco advertising bans through traditional marketing channels have made packaging increasingly important as a marketing vehicle, not just in Mexico but around the world. ${ }^{22-25}$ We hypothesised that recall of brand names, pack attractiveness and willingness to try will be greater for FCVs compared with non-FCVs. Furthermore, we expected that brand recall, attractiveness and willingness to try would be positively associated with prior advertising exposures, particularly through point of sale (PoS), where cigarette pack displays remain a key marketing strategy.

\section{METHODS}

\section{Sample}

In February and March 2015, data were collected from 10124 first year students in public middle schools (ages 11-16 years; mean age 12.4 years) who were randomly selected from the three largest cities in Mexico (Mexico City, Guadalajara, Monterrey). Sampling strata were based on levels of socioeconomic marginalisation (high vs low) for the census tract where the school was located, and on tertiles of the density of retail establishments that were likely to sell tobacco around the schools. Within each of these six strata, three or four schools were randomly selected with a selection probability proportional to the number of students in each school, with a quota of 20 schools per city. A replacement school was selected randomly from the same stratum if a school did not agree to participate. A passive consent procedure was used for parental consent, with students providing active consent. The study protocol was approved by the ethics committee at the Mexican National Institute of Public Health (INSP).

\section{Measures}

At school and during class time, students self-administered a 30-40 min pencil-and-paper Spanish language survey on tobacco-related and alcohol-related perceptions and behaviour, as well as media use. Students were randomised to view a set of three cigarette packs printed in colour with brand names digitally removed. Each set of three pack stimuli included one pack from each major brand family (ie, Marlboro, Camel, Pall Mall), with one regular, one light and one capsule variety shown. Four varieties were used for each brand family: one regular, one light, one regular cigarette with capsule and one menthol cigarette with capsule (see table 1). Menthol-flavoured tobacco varieties were not included because not all three brand families included a mentholated tobacco variety at the time of the study. This resulted in 12 different combinations of three packs, each of which had three distinct presentation orders from left to right, so that the design controlled for any biases from the order of pack presentation.

\section{Pack attributes}

Dummy variables were derived for brand family (Marlboro as the reference because of its market dominance among both adults $^{21}$ and youth ${ }^{26}$ ), FCV (yes vs no), and combinations of brand and FCV. For assessing interactions between brand family and flavour capsule, Marlboro regular/light was used as a reference because of its market dominance.

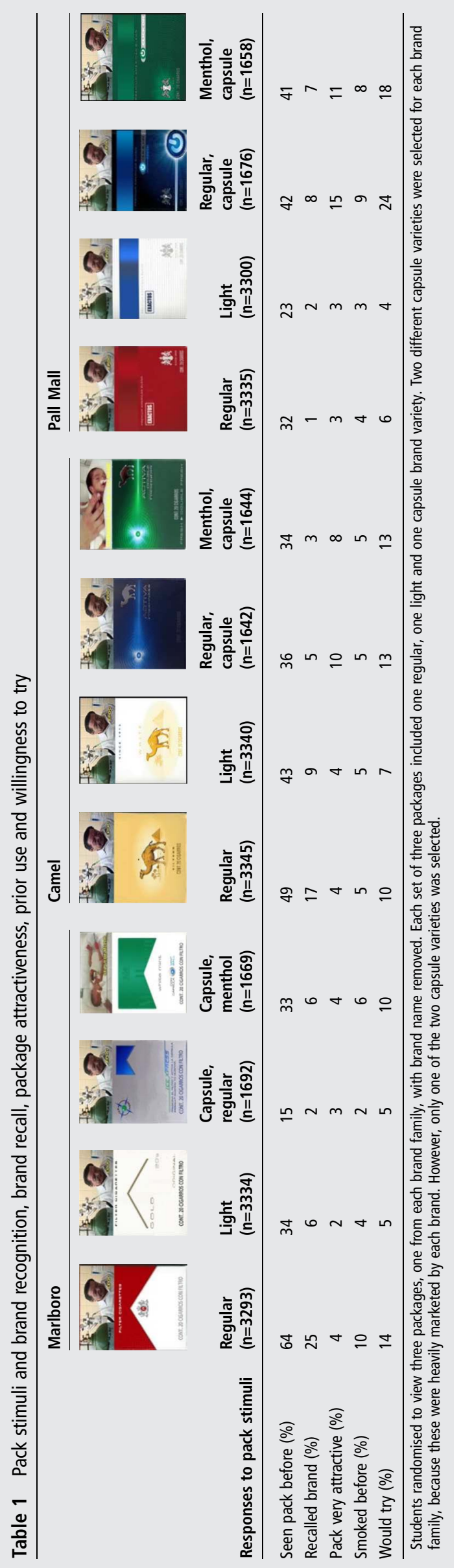


Perceptions and use of brand varieties

For each pack, students reported having seen it ('Have you ever seen this brand of cigarettes?' no vs yes) and if they have smoked it before ('Have you ever used this brand?' no vs yes). Similar to studies of media advertising ${ }^{27}$ cued brand recall was assessed by asking students to write out the brand name for each pack. Misspelt brand names were classified as correctly recalled if the letters used clearly distinguished the brand family from others (eg, 'Marbro'). Students also evaluated pack attractiveness ('How much do you like the look of the pack?' not at all=0; a little=1; a lot=2). Finally, students were asked about their interest in trying one of the packs they evaluated ('If you were to try smoking one of these brands, which would you try (choose just one option)?'), with a clear option to indicate 'I would not try any of these brands'.

\section{Exposure to tobacco promotions at PoS}

As in prior research ${ }^{29}$ and validated for Argentine youth, ${ }^{27}$ students reported the frequency of visiting retail environments that were likely to sell tobacco (ie, 'tiendas') in the prior month, both with reference to stores around their schools (ie, 'less than five blocks away') and further away from them (ie, 'five or more blocks away'). Responses to these questions ( $1=$ never, $2=$ sometimes, $3=$ often, $4=$ very often) were summed (range 1-8) and participants were classified into tertiles.

\section{Control variables}

Control variables included an indicator of whether students have smoked before the brand variety (no vs yes) and demographic variables such as age (12 and younger, 13, 14 and older), sex and the highest level of education attained by either parent (ie, primary school completed, including secondary school incomplete; completed secondary school, including incomplete high school or technical school; completed high school or technical school, including incomplete university; completed university or more; don't know for either parent), which has been used as a proxy for socioeconomic status (SES) among early adolescents. ${ }^{30-32}$ Smoking-related risk factors included smoking status of parents (either/both vs none), siblings (any vs none) and five closest friends (any vs none); positive expectancies about smoking conventional cigarettes using five questions adapted from prior research ${ }^{33}$ (eg, 'Smoking is cool'; 'Smoking makes you look older'), to which students indicated level of agreement $(\alpha=0.89)$; internet exposure to tobacco product advertising ('When you are on the internet, how often do you see advertising for cigarettes or any other tobacco product?" $0=$ never; $1=$ 'rarely' or 'sometimes'; $2=$ 'mostly' or 'always'); and a four-item sensation-seeking scale ${ }^{34}$ (eg, 'I like to do frightening things'; $\alpha=0.80$ ), which has been validated for Mexican youth. ${ }^{35}$ Standard assessments of current smoking behaviour and smoking susceptibility were used to derive four levels of smoking involvement: non-susceptible never-smoker (reference group), susceptible never-smoker; experimenters who reported having tried cigarettes, but not in the past 30 days; current smokers who reported smoking in the prior 30 days. Susceptibility was determined through validated questions about intention to smoke both during the next year and if a friend offered a cigarette, with those who were not entirely closed to smoking being classified as susceptible. ${ }^{36}$

\section{Analysis}

All analyses were undertaken using Stata V.13. Missing data for individual variables were generally low $(0-5.4 \%)$, so observations with any missing values were excluded from the analyses.
Omnibus $\chi^{2}$ tests were conducted to assess differences in sociodemographic and smoking-related variables associated with students who evaluated each of the 12 cigarette packs that were presented. Descriptive frequencies for the five responses to each pack stimulus were assessed (seen pack before, recalled brand, pack attractiveness, having smoked it before and interest in trying it). Then weighted generalised estimating equation (GEE) models with the binomial distribution and logit link function were estimated, separately regressing three dependent variables (brand recall (no vs yes); pack attractiveness (a lot vs a little or not at all); interest in trying (no vs yes)) on study variables. Weights reflected the inverse probability of school selection in the sample. Both unadjusted and adjusted models were estimated, with adjusted models including indicators for pack attributes (ie, brand family, flavour capsule), frequency of visiting PoS, sociodemographics, smoking-related risk factors and having smoked the brand variety before. Finally, pack attractiveness (ie, not at all, a little, a lot) was also included in models assessing interest in trying. After assessing the main effects of brand family and FCVs, models were re-estimated using a series of indicator variables for the combination of brand family (Marlboro, Camel, Pall Mall) and FCVs (yes vs no), with Marlboro regular/light as the reference group. Sensitivity analyses were conducted for all models after limiting the analytic sample to never-smokers, eliminating prior trial of the variety and ever use of tobacco from the models. Furthermore, the model predicting pack attractiveness was estimated after recoding the dependent variable (ie, 'a lot' vs 'a little' or 'not at all'). Since results were consistent across models in terms of direction, strength and statistical significance of coefficients $(p<0.05)$, only the results for the entire study sample are reported here.

\section{RESULTS}

The school participation rate was 92\% (60/65 schools invited). Within these schools, the student participation rate was $84 \%$ (11\% absent on survey date; $5 \%$ of parents refused permission; $0.02 \%$ of students refused to participate). Participants (Mexico City $n=3486$, Guadalajara $n=3461$, Monterrey $n=3176$ ) included an equal proportion of males and females and a mean age of 12.4 years old (age range 11-16 years; see table 2). Approximately $43 \%$ of students had a parent who smoked and $35 \%$ had at least one close friend who smoked. Three-quarters of students reported never smoking, with 19\% being susceptible to smoke and $8 \%$ currently smoking. The profiles of students assigned to evaluate each cigarette package variety were not significantly different for any sociodemographic or smoking-related variable that we assessed (see online supplementary appendix), suggesting that the randomisation scheme was successful.

Brand varieties with the highest levels of recognition (ie, having seen before) and correct brand recall were Marlboro regular (64\% and 25\%, respectively), Camel regular (49\% and $17 \%$, respectively), Camel light (43\% and 9\%, respectively) and Pall Mall FCVs (42\% and 8\%, respectively; see table 1). Ratings for very attractive packaging were highest for Pall Mall FCVs (13\%) and Camel FCVs (9\%), with these varieties also being rated highest for interest in trial (22\% and 13\%, respectively), along with Marlboro regular (14\%). Marlboro regular (10\%) and the two Pall Mall FCVs (regular flavour with capsule=9\%; menthol flavour with capsule $=8 \%$ ) were most often reported as the brand varieties that they had smoked before.

In GEE models assessing the main effects of flavour capsules (table 3), FCVs were no more likely to be recalled than non-FCVs; however, FCVs were associated with a greater 
Table 2 Sample characteristics

\begin{tabular}{|c|c|}
\hline Characteristics & n (\%) \\
\hline \multicolumn{2}{|l|}{ Sex } \\
\hline Female & $5049(50)$ \\
\hline \multicolumn{2}{|l|}{ Age } \\
\hline 11 or 12 & $6191(62)$ \\
\hline 13 & $3470(34)$ \\
\hline 14 or more & $431(4)$ \\
\hline \multicolumn{2}{|l|}{ Parents' education } \\
\hline Up to primary school complete & $2171(22)$ \\
\hline Completed secondary school & $3799(38)$ \\
\hline Completed high school or technical school & $1626(16)$ \\
\hline Completed university or more & $1573(16)$ \\
\hline Don't know & $858(9)$ \\
\hline \multicolumn{2}{|l|}{ Internet ad exposure } \\
\hline Never & $5068(50)$ \\
\hline Rarely/sometimes & $4205(42)$ \\
\hline Mostly/always & $770(8)$ \\
\hline \multicolumn{2}{|l|}{ PoS exposure } \\
\hline Low & $4337(43)$ \\
\hline Medium & $4304(43)$ \\
\hline High & $1472(14)$ \\
\hline Parental smoking & $4313(43)$ \\
\hline Sibling(s) smoking & $1580(16)$ \\
\hline Any friend smokes & $3577(35)$ \\
\hline Sensation seeking $(1-5)$ mean (SD) & $2.88(1.05)$ \\
\hline Positive expectancies (1-5) mean (SD) & $1.82(0.92)$ \\
\hline \multicolumn{2}{|l|}{ Smoking } \\
\hline Never-smoker, not susceptible & $5652(57)$ \\
\hline Never-smokers, susceptible & $1936(19)$ \\
\hline Experimenters & $1637(16)$ \\
\hline Current smokers & $826(8)$ \\
\hline
\end{tabular}

likelihood of perceived pack attractiveness (adjusted OR $(\mathrm{AOR})=1.83,95 \% \mathrm{CI} 1.72$ to 1.94$)$ and interest in trying (AOR $=1.74,95 \%$ CI 1.54 to 1.96$)$. Prior use was positively associated with brand recall, pack attractiveness and interest in trying. Furthermore, perceived attractiveness was strongly and independently associated with greater interest in trying $\left(\mathrm{AOR}_{\mathrm{a}}\right.$ little vs not at all $=3.23,95 \%$ CI 2.87 to 3.62 ; $\mathrm{AOR}_{\mathrm{a}}$ lot vs not at all $=5.63,95 \% \mathrm{CI} 4.74$ to 6.69 ). In bivariate models, both the frequency of PoS visits and internet ad exposure were positively associated with all three outcomes assessed; however, these associations remained statistically significant only in the model for rating packs as attractive (PoS exposure $\mathrm{AOR}_{\text {low vs high }}=1.43,95 \%$ CI 1.25 to 1.63 ; internet exposure $\mathrm{AOR}_{\text {low vs high }}=1.48,95 \%$ CI 1.26 to 1.73 ).

When GEE models included indicators that combined brand family with FCVs (see table 4), FCVs from all brand families (Marlboro, Camel and Pall Mall) were less likely to be recalled in comparison with non-FCVs for Marlboro. In contrast, when compared with Marlboro non-FCVs, Camel FCVs and Pall Mall FCVs had greater odds of being perceived as having very attractive packaging $\left(\mathrm{AOR}_{\mathrm{Camel}} \mathrm{FCV}\right.$ vs Marlboro non-FCV $=2.57,95 \% \mathrm{CI}$ 2.32 to 2.83; AOR $_{\text {Pall }}$ Mall FCV vs Marlboro non-FCV $=3.30,95 \%$ CI 2.97 to 3.66) and for being of greatest interest for trying $\left(\mathrm{AOR}_{\text {Camel FCV vs Marlboro non-FCV }}=1.36,95 \%\right.$ CI 1.10 to 1.66 ; $\mathrm{AOR}_{\text {Pall Mall FCV vs Marlboro non-FCV }}=1.99$, 95\% CI 1.65 to 2.39 ). The direction, strength and statistical significance of other correlates in the adjusted models were consistent with the main effects models, so these results are not reported (available on request).

\section{DISCUSSION}

The results from this study suggest that FCV cigarettes appeal to early adolescents in Mexico. In particular, the attractiveness of FCV packaging and interest in trying FCVs was higher than for non-FCV Marlboro varieties, in spite of the generally greater brand awareness for non-FCVs of Marlboro and Camel. It is unsurprising that non-FCV Marlboros and Camels were most commonly recognised and recalled. More than half of the Mexican adult smokers prefer Marlboro regular, ${ }^{13}{ }^{37}$ which most likely creates more opportunities for youth to be exposed to Marlboro through social exposures. Indeed, data from the most recent Global Youth Tobacco Survey in Mexico in 2011 indicate that Marlboro was the most frequently known and used brand of cigarettes among 12-15-year olds. ${ }^{26}$ Furthermore, Camel has aggressively targeted the youth market over the past 15 years, with an increasing emphasis on innovative packagebased marketing strategies that have been accompanied by significant growth in the market share of Camel among young adults. ${ }^{38}$ Among young adolescents, the novelty and innovation of FCVs, which were introduced in 2011-2012, appear to be generating an even greater appeal than established non-FCVs in dominant brand families. This is reason for concern, as innovative FCVs may be sustaining and perhaps even expanding the cigarette market among youth.

Pall Mall FCVs appeared particularly attractive for young adolescents in this study, perhaps reflecting the proliferation of FCV varieties (16 in 2013) and the significant growth of the Pall Mall market share since FCVs were introduced. ${ }^{39}$ While data on this growth include adult smokers, our results suggest that FCVs and their packaging designs are particularly attractive for early adolescents, which is a population segment that is critical for ensuring the future livelihood of the tobacco industry. That Pall Mall cigarettes are also marketed at discount prices ${ }^{21}$ may further explain their appeal for youth, who are known to be price-sensitive. Furthermore, industry documents suggest that FCV designs may be attractive to youth precisely because they are innovative, generate word of mouth 'buzz' and promote the notion of 'choice' about if and when to activate the flavour capsule. ${ }^{40}$ Indeed, FCVs appear more attractive to younger than older adults in Australia, where plain packaging has been implemented, suggesting that such FCV product design characteristics remain important even in the absence of package-based marketing. ${ }^{941}$

Future research should consider exploring whether FCVs promote misperceptions of relative risk, as found among some adult smokers. ${ }^{9}$ Data on such misperceptions around mentholflavoured tobacco ${ }^{9-12}$ have supported efforts to ban both menthol-flavoured tobacco and FCVs in the European Union's Tobacco Product Directive. ${ }^{42}$ Recent rulings by the US Food and Drug Administration removed the most dominant FCV from the US market (ie, Camel Crush) because of concerns about its potential threat to public health, a decision that was presumably founded on similar concerns. ${ }^{43}$ Menthol bans have even been adopted at the subnational, provincial level in Canada (ie, Nova Scotia, Alberta, Ontario, Quebec, New Brunswick and Prince Edward Island) ${ }^{44}$, suggesting that local jurisdictions may consider similar measures in some countries.

Our results also suggest that marketing through PoS and the internet may also promote brand awareness, appeal and willingness to try cigarettes. These marketing exposures had an independent, statistically significant association with ratings of pack 
Table 3 Correlates of brand name recall, package attractiveness and interest in trying among Mexican youth

\begin{tabular}{|c|c|c|c|c|c|c|}
\hline \multirow[b]{3}{*}{ Sample and pack characteristics } & \multicolumn{6}{|c|}{ Outcome variable } \\
\hline & \multicolumn{2}{|c|}{ Recalled brand name } & \multicolumn{2}{|c|}{ Package very attractive } & \multicolumn{2}{|l|}{ Would try } \\
\hline & OR & AORT & OR & AORT & OR & AORt \\
\hline Parental smoking (yes vs no) & $\begin{array}{l}1.59^{* * *} \\
(1.42 \text { to } 1.78)\end{array}$ & $\begin{array}{l}1.55^{* * *} \\
(1.40 \text { to } 1.70)\end{array}$ & $\begin{array}{l}1.48^{* * *} \\
(1.18 \text { to } 1.86)\end{array}$ & $\begin{array}{l}1.19^{* * *} \\
\text { (1.08 to } 1.30)\end{array}$ & $\begin{array}{l}1.74^{* * *} \\
\text { (1.56 to } 1.94)\end{array}$ & $\begin{array}{l}1.10 \\
(0.99 \text { to } 1.20)\end{array}$ \\
\hline Sibling(s) smoking (yes vs no) & $\begin{array}{l}1.35^{* * *} \\
\text { (1.21 to } 1.51)\end{array}$ & $\begin{array}{l}0.98 \\
(0.86 \text { to } 1.11)\end{array}$ & $\begin{array}{l}1.79^{* * *} \\
(1.51 \text { to } 2.12)\end{array}$ & $\begin{array}{l}1.08 \\
(0.95 \text { to } 1.21)\end{array}$ & $\begin{array}{l}1.92^{* * *} \\
(1.75 \text { to } 2.10)\end{array}$ & $\begin{array}{l}1.16^{* *} \\
\text { (1.03 to } 1.29)\end{array}$ \\
\hline Any friend smokes (yes vs no) & $\begin{array}{l}1.49^{* * *} \\
\text { (1.37 to } 1.63)\end{array}$ & $\begin{array}{l}1.1 \\
(0.98 \text { to } 1.21)\end{array}$ & $\begin{array}{l}2.40^{* * *} \\
\text { (2.05 to } 2.81 \text { ) }\end{array}$ & $\begin{array}{l}1.36^{* * *} \\
\text { (1.22 to } 1.49)\end{array}$ & $\begin{array}{l}2.58^{* * *} \\
(2.38 \text { to } 2.81 \text { ) }\end{array}$ & $\begin{array}{l}1.22^{* * *} \\
(1.10 \text { to } 1.35)\end{array}$ \\
\hline Sensation seeking (1-5) & $\begin{array}{l}1.17^{* * *} \\
(1.12 \text { to } 1.22)\end{array}$ & $\begin{array}{l}1.01 \\
(0.96 \text { to } 1.06)\end{array}$ & $\begin{array}{l}1.53^{* * *} \\
(1.41 \text { to } 1.66)\end{array}$ & $\begin{array}{l}1.14^{* * *} \\
\text { (1.09 to } 1.20)\end{array}$ & $\begin{array}{l}1.47^{* * *} \\
(1.42 \text { to } 1.53)\end{array}$ & $\begin{array}{l}1.08^{* *} \\
(1.02 \text { to } 1.14)\end{array}$ \\
\hline Positive expectancies (1-5) & $\begin{array}{l}1.20^{* * *} \\
(1.15 \text { to } 1.25)\end{array}$ & $\begin{array}{l}0.96 \\
(0.90 \text { to } 1.01)\end{array}$ & $\begin{array}{l}1.77^{* * *} \\
(1.65 \text { to } 1.90)\end{array}$ & $\begin{array}{l}1.17^{* * *} \\
\text { (1.09 to } 1.23)\end{array}$ & $\begin{array}{l}1.66^{* * *} \\
\text { (1.60 to } 1.72)\end{array}$ & $\begin{array}{l}1.09 * * \\
\text { (1.03 to } 1.15)\end{array}$ \\
\hline \multicolumn{7}{|c|}{ Smoking (vs never-smoker, not susceptible) } \\
\hline Never-smoker, susceptible & $\begin{array}{l}1.43^{* * *} \\
(1.27 \text { to } 1.61)\end{array}$ & $\begin{array}{l}1.27^{* * *} \\
(1.11 \text { to } 1.45)\end{array}$ & $\begin{array}{l}2.01^{* * *} \\
(1.60 \text { to } 2.53)\end{array}$ & $\begin{array}{l}1.66^{* * *} \\
(1.46 \text { to } 1.88)\end{array}$ & $\begin{array}{l}3.25^{* * *} \\
\text { (2.89 to } 3.66)\end{array}$ & $\begin{array}{l}2.14^{* * *} \\
\text { (1.86 to } 2.44)\end{array}$ \\
\hline Experimenter & $\begin{array}{l}1.98^{* * *} \\
\text { (1.78 to } 2.22 \text { ) }\end{array}$ & $\begin{array}{l}1.32^{* * *} \\
(1.15 \text { to } 1.51)\end{array}$ & $\begin{array}{l}2.99^{* * *} \\
(2.42 \text { to } 3.69)\end{array}$ & $\begin{array}{l}1.91^{* * *} \\
(1.67 \text { to } 2.16)\end{array}$ & $\begin{array}{l}4.44^{* * *} \\
\text { (3.97 to } 4.97)\end{array}$ & $\begin{array}{l}2.05^{* * *} \\
\text { (1.78 to } 2.35)\end{array}$ \\
\hline Current smoker & $\begin{array}{l}2.35^{* * *} \\
\text { (2.06 to } 2.68)\end{array}$ & $\begin{array}{l}1.13 \\
(0.93 \text { to } 1.37)\end{array}$ & $\begin{array}{l}5.59^{* * *} \\
(4.50 \text { to } 6.95)\end{array}$ & $\begin{array}{l}1.88^{* * *} \\
\text { (1.56 to } 2.25)\end{array}$ & $\begin{array}{l}6.89^{* * *} \\
(6.17 \text { to } 7.71)\end{array}$ & $\begin{array}{l}1.75^{* * *} \\
\text { (1.46 to } 2.08)\end{array}$ \\
\hline \multicolumn{7}{|l|}{ Internet ad exposure (vs never) } \\
\hline Rarely/sometimes & $\begin{array}{l}1.23^{* * *} \\
(1.12 \text { to } 1.35)\end{array}$ & $\begin{array}{l}1.14^{* *} \\
(1.03 \text { to } 1.25)\end{array}$ & $\begin{array}{l}1.19^{*} \\
\text { (1.01 to } 1.41)\end{array}$ & $\begin{array}{l}1.31^{* * *} \\
(1.19 \text { to } 1.44)\end{array}$ & $\begin{array}{l}1.31^{* * *} \\
(1.20 \text { to } 1.44)\end{array}$ & $\begin{array}{l}1.03 \\
\text { (0.92 to } 1.12)\end{array}$ \\
\hline Mostly/always & $\begin{array}{l}1.38^{* * *} \\
\text { (1.18 to } 1.62)\end{array}$ & $\begin{array}{l}1.07 \\
(0.90 \text { to } 1.27)\end{array}$ & $\begin{array}{l}2.46^{* * *} \\
\text { (1.93 to } 3.14)\end{array}$ & $\begin{array}{l}1.48^{* * *} \\
\text { (1.26 to } 1.73)\end{array}$ & $\begin{array}{l}1.94^{* * *} \\
(1.70 \text { to } 2.22)\end{array}$ & $\begin{array}{l}1.11 \\
\text { (0.95 to } 1.28)\end{array}$ \\
\hline \multicolumn{7}{|l|}{ PoS exposure (vs low) } \\
\hline Medium & $\begin{array}{l}1.19^{* * *} \\
\text { (1.08 to } 1.32)\end{array}$ & $\begin{array}{l}1.07 \\
(0.96 \text { to } 1.19)\end{array}$ & $\begin{array}{l}1.49^{* * *} \\
(1.24 \text { to } 1.80)\end{array}$ & $\begin{array}{l}1.18^{* *} \\
(1.06 \text { to } 1.30)\end{array}$ & $\begin{array}{l}1.58^{* * *} \\
\text { (1.43 to } 1.74)\end{array}$ & $\begin{array}{l}1.14^{*} \\
\text { (1.03 to } 1.27)\end{array}$ \\
\hline High & $\begin{array}{l}1.53^{* * *} \\
\text { (1.36 to } 1.74)\end{array}$ & $\begin{array}{l}1.22^{* *} \\
(1.06 \text { to } 1.40)\end{array}$ & $\begin{array}{l}2.56^{* * *} \\
\text { (2.06 to } 3.18)\end{array}$ & $\begin{array}{l}1.43^{* * *} \\
(1.25 \text { to } 1.63)\end{array}$ & $\begin{array}{l}1.95^{* * *} \\
(1.74 \text { to } 2.20)\end{array}$ & $\begin{array}{l}0.95 \\
(0.82 \text { to } 1.09)\end{array}$ \\
\hline Smoked brand before (yes vs no) & $\begin{array}{l}5.04^{* * *} \\
(4.47 \text { to } 5.70)\end{array}$ & $\begin{array}{l}4.56^{* * *} \\
(3.85 \text { to } 5.41)\end{array}$ & $\begin{array}{l}5.10^{* * *} \\
(4.15 \text { to } 6.28)\end{array}$ & $\begin{array}{l}2.92^{* * *} \\
\text { (2.46 to } 3.47)\end{array}$ & $\begin{array}{l}10.11^{* * *} \\
(9.07 \text { to } 11.28)\end{array}$ & $\begin{array}{l}4.48^{* * *} \\
\text { (3.81 to } 5.26 \text { ) }\end{array}$ \\
\hline \multicolumn{7}{|l|}{ Pack attractive (vs no) } \\
\hline A little & & & & & $\begin{array}{l}5.12^{* * *} \\
(4.61 \text { to } 5.68)\end{array}$ & $\begin{array}{l}3.23^{* * *} \\
\text { (2.87 to } 3.62)\end{array}$ \\
\hline A lot & & & & & $\begin{array}{l}11.94^{* * *} \\
\text { (10.28 to } 13.88)\end{array}$ & $\begin{array}{l}5.63^{* * *} \\
(4.74 \text { to } 6.68)\end{array}$ \\
\hline \multicolumn{7}{|l|}{ Brand family (vs Marlboro) } \\
\hline Camel & $\begin{array}{l}1.01 \\
(0.90 \text { to } 1.14)\end{array}$ & $\begin{array}{l}1.03 \\
(0.90 \text { to } 1.16)\end{array}$ & $\begin{array}{l}1.67^{* * *} \\
\text { (1.43 to } 1.96)\end{array}$ & $\begin{array}{l}1.88^{* * *} \\
\text { (1.74 to } 2.01)\end{array}$ & $\begin{array}{l}1.19^{* *} \\
(1.05 \text { to } 1.36)\end{array}$ & $\begin{array}{l}1.06 \\
(0.91 \text { to } 1.22)\end{array}$ \\
\hline Pall Mall & $\begin{array}{l}0.24^{* * *} \\
(0.20 \text { to } 0.28)\end{array}$ & $\begin{array}{l}0.24^{* * *} \\
(0.20 \text { to } 0.28)\end{array}$ & $\begin{array}{l}1.80^{* * *} \\
(1.55 \text { to } 2.10)\end{array}$ & $\begin{array}{l}1.56^{* * *} \\
\text { (1.45 to } 1.67)\end{array}$ & $\begin{array}{l}1.13^{*} \\
(1.00 \text { to } 1.29)\end{array}$ & $\begin{array}{l}1.02 \\
(0.88 \text { to } 1.18)\end{array}$ \\
\hline Flavour capsule (vs not) & $\begin{array}{l}0.45^{* * *} \\
(0.39 \text { to } 0.51)\end{array}$ & $\begin{array}{l}0.43^{* * *} \\
(0.37 \text { to } 0.49)\end{array}$ & $\begin{array}{l}2.41^{* * *} \\
\text { (2.14 to } 2.72 \text { ) }\end{array}$ & $\begin{array}{l}1.83^{* * *} \\
\text { (1.72 to } 1.94)\end{array}$ & $\begin{array}{l}1.84^{* * *} \\
\text { (1.66 to } 2.04)\end{array}$ & $\begin{array}{l}1.74^{* * *} \\
\text { (1.54 to } 1.96)\end{array}$ \\
\hline
\end{tabular}

tAdjusted models include all the variables shown in the table, as well as age, sex and parental education.

AOR, adjusted OR; PoS, point of sale.

attractiveness, which in turn were independently associated with a willingness to try particular brand varieties. Since PoS promotions, pack displays and the internet have become primary channels through which the industry promotes tobacco, ${ }^{27} 45-49$ future research on these channels should determine the longitudinal associations between smoking onset and these, as well as other, marketing exposures.

Conclusions from this cross-sectional study are limited. Our suggestion that package-based brand recall, pack attractiveness and interest in trying different cigarette brands are predictive of the likelihood of smoking initiation and progression should be confirmed with longitudinal research. Nevertheless, the brand-recall measures are similar to those used in other advertising research, ${ }^{28}$ even though they remain to be validated when anchored to package imagery. Still, the construct validity of our measurement approach is supported by the expected correlations with other study variables in this and another study among similarly aged youth. ${ }^{27}$ This approach to studying brand recall and advertising impact is particularly pertinent given the growing importance of pack-based marketing. ${ }^{50}$ Our assessment of pack attractiveness and willingness to try is similar to approaches used in industry studies, ${ }^{51}$ suggesting their validity. Our study design did not include an assessment of flavoured tobacco without capsules, so we were unable to determine whether the flavour or the capsules mattered more. This decision was made because the flavoured tobacco market segment in Mexico is small and was not represented in all brand families that were used for this study. Nevertheless, future experimental research should assess comparisons with flavoured tobacco while exploring the independent impact of 
Table 4 Brand name recall, package attractiveness and interest in trying brand-specific varieties among Mexican youth

\begin{tabular}{|c|c|c|c|c|c|c|c|c|c|}
\hline \multirow[b]{2}{*}{ Sample and pack characteristics } & \multicolumn{3}{|c|}{ Recalled brand name } & \multicolumn{3}{|c|}{ Package very attractive } & \multicolumn{3}{|c|}{ Would try } \\
\hline & Per cent & OR & AOR & Per cent & OR & AOR§ & Per cent & OR & AORף \\
\hline \multicolumn{10}{|l|}{ Brand×flavour capsule } \\
\hline Marlboro, regular/light (ref) & 16 & 1 & 1 & 3 & 1 & 1 & 9 & 1 & 1 \\
\hline Marlboro, capsule & 4 & $\begin{array}{l}0.26^{* * *} \\
(0.21 \text { to } 0.32)\end{array}$ & $\begin{array}{l}0.26^{* * *} \\
(0.20 \text { to } 0.32)\end{array}$ & 4 & $\begin{array}{l}0.89 \\
\text { (0.66 to } 1.19)\end{array}$ & $\begin{array}{l}0.91 \\
(0.79 \text { to } 1.02)\end{array}$ & 7 & $\begin{array}{l}0.88 \\
(0.73 \text { to } 1.06)\end{array}$ & $\begin{array}{l}0.99 \\
(0.80 \text { to } 1.21)\end{array}$ \\
\hline Camel, regular/light & 13 & $\begin{array}{l}1.02 \\
(0.90 \text { to } 1.15)\end{array}$ & $\begin{array}{l}1.04 \\
\text { (0.91 to } 1.191)\end{array}$ & 4 & $\begin{array}{l}1.13 \\
(0.93 \text { to } 1.38)\end{array}$ & $\begin{array}{l}1.49^{* * *} \\
\text { (1.36 to } 1.63)\end{array}$ & 8 & $\begin{array}{l}0.98 \\
(0.84 \text { to } 1.14)\end{array}$ & $\begin{array}{l}0.93 \\
(0.78 \text { to } 1.11)\end{array}$ \\
\hline Camel, capsule & 4 & $\begin{array}{l}0.25^{* * *} \\
(0.20 \text { to } 0.32)\end{array}$ & $\begin{array}{l}0.25^{* * *} \\
(0.19 \text { to } 0.31)\end{array}$ & 9 & $\begin{array}{l}2.67^{* * *} \\
\text { (2.18 to } 3.26)\end{array}$ & $\begin{array}{l}2.57^{* * *} \\
\text { (2.32 to } 2.83 \text { ) }\end{array}$ & 13 & $\begin{array}{l}1.51^{* * *} \\
(1.27 \text { to } 1.80)\end{array}$ & $\begin{array}{l}1.36^{* *} \\
\text { (1.10 to } 1.66)\end{array}$ \\
\hline Pall Mall, regular/light & 2 & $\begin{array}{l}0.07^{* * *} \\
(0.06 \text { to } 0.09)\end{array}$ & $\begin{array}{l}0.07^{* * *} \\
(0.05 \text { to } 0.09)\end{array}$ & 3 & $\begin{array}{l}0.82 \\
(0.66 \text { to } 1.01)\end{array}$ & $\begin{array}{l}0.93 \\
(0.84 \text { to } 1.02)\end{array}$ & 5 & $\begin{array}{l}0.55^{* * *} \\
(0.46 \text { to } 0.65)\end{array}$ & $\begin{array}{l}0.57^{* * *} \\
(0.46 \text { to } 0.69)\end{array}$ \\
\hline Pall Mall, capsule & 8 & $\begin{array}{l}0.38^{* * *} \\
(0.32 \text { to } 0.46)\end{array}$ & $\begin{array}{l}0.36^{* * *} \\
(0.29 \text { to } 0.44)\end{array}$ & 13 & $\begin{array}{l}3.75^{* * *} \\
\text { (3.16 to } 4.51 \text { ) }\end{array}$ & $\begin{array}{l}3.30^{* * *} \\
\text { (2.97 to } 3.66 \text { ) }\end{array}$ & 21 & $\begin{array}{l}2.29^{* * *} \\
\text { (1.96 to } 2.69)\end{array}$ & $\begin{array}{l}1.99^{* * *} \\
\text { (1.65 to } 2.39)\end{array}$ \\
\hline
\end{tabular}

${ }^{*} \mathrm{p}<0.05 ;{ }^{* *} \mathrm{p}<0.01 ;{ }^{* * *} \mathrm{p}<0.00$

†Adjusted models account for age, sex, parental education, parental smoking, sibling smoking, friend smoking, sensation seeking, positive expectancies, smoking status (never-smoker, not susceptible; never-smoker, susceptible; prior trial, not current smoker; current smoker), frequency of internet tobacco ad exposure and frequency of PoS exposure.

¥Adjusted models account for those listed under 1 , as well as report having smoked the brand variety before.

§Adjusted models account for those listed under 1, as well as report having smoked the brand variety before, and rating of pack attractiveness.

IStudents were presented with three packs and asked which cigarettes, if any, they would want to try, including the option of not wanting to smoke any of the brands.

AOR, adjusted OR; POS, point of sale.

the flavour capsule. Finally, our study results may not generalise to the broader Mexican population. Private schools were not included in our sampling frame, and adolescents who attend private school are more likely than public school students to come from higher SES groups. Higher parental education was only marginally associated with a greater recall and willingness to try, suggesting that the exclusion of private school students may have led to minor underestimates of effects. Along with the relatively low percentage of private school students in the general population (4.2\%), ${ }^{52}$ these results suggests that the omission of private schools is unlikely to have seriously biased the results or their interpretation. Although our sample did not include any rural areas, three-quarters of Mexicans live in urban areas, and we sampled the three largest urban areas, so our results are reasonably generalisable. Furthermore, we sampled schools from a range of SES neighbourhoods and density of PoS retail environments. These factors, along with high participation rates and the large sample size, suggest that

\section{What this paper adds}

- Flavour capsule brand varieties of cigarettes are available in most markets, and industry reports document explosive growth in some countries.

- Preference for flavour capsules is associated with greater appeal and reduced harm perception among adult smokers. No quantitative data exist on the potential appeal of flavour capsules among adolescents in any country.

- This study indicates that flavour capsule varieties of cigarettes are appealing to early adolescents, who report a greater appeal than established cigarette varieties in dominant brand families.

- Our package-based approach to assessing marketing effects on youth recognises the increasing importance of packaging for communicating brand imagery where advertising through traditional channels is banned, as is increasingly the case around the world. the study results are reasonably generalisable to public school students in urban areas.

In spite of these limitations, these results suggest that FCVs appeal to youth and that this innovative product design and associated package-based marketing may promote tobacco use. Our package-based approach to assessing brand recall and adolescent responses to package design recognises the increasing importance of packaging for communicating brand imagery where traditional advertising channels are banned, as is increasingly the case around the world. The results suggest that FCVs should be targeted for regulation, particularly given the substantial growth with which they are associated in a variety of markets.

Contributors All authors made a substantial contribution to this research; JFT and JDS designed the data collection tools and conceptualised the study and analytic approach; JFT and ENA-V wrote the initial draft of the manuscript; ENA-V conducted the statistical analyses; EA-S, RP-H, IB-G, CK-C and JDS provided substantial contributions to the writing and finalisation of the manuscript. All authors revised the manuscript and gave final approval to the version to be published.

Funding This research was supported by a grant from the Fogarty International Center and the National Cancer Institute, from the United States National Institutes of Health (grant number R01 TW009274). The content is solely the responsibility of the authors and does not necessarily represent the official views of the National Institutes of Health.

Disclaimer The content is solely the responsibility of the authors and does not necessarily represent the official views of the National Institutes of Health.

Competing interests None declared.

Ethics approval The ethics committee at the Mexican National Institute of Public Health (INSP) approved the study protocol.

Provenance and peer review Not commissioned; externally peer reviewed.

Data sharing statement Additional unpublished data from the study are available on request from the main investigators by email.

Open Access This is an Open Access article distributed in accordance with the Creative Commons Attribution Non Commercial (CC BY-NC 4.0) license, which permits others to distribute, remix, adapt, build upon this work non-commercially, and license their derivative works on different terms, provided the original work is properly cited and the use is non-commercial. See: http://creativecommons.org/ licenses/by-nc/4.0/

\section{REFERENCES}

1 Managing the challenges in Western Europe. British American Tobacco. Hampshire, UK, 2011. 
2 Cobben M. Capsule rollout. Secondary Capsule rollout 2011. http://www.bat.com/ group/sites/UK__9ZTFCM.nsf/vwPagesWebLive/D08GLLKH/\$FILE/14_Mark Cobben -Capsule Rollout.pdf?openelement

3 Gilmore $A B$. Understanding the vector in order to plan effective tobacco control policies: an analysis of contemporary tobacco industry materials. Tob Control 2012;21:119-26.

4 Kahnert S, Pötschke-Langer M, Schunk S, et al. Menthol capsules in cigarette filters -increasing the attractiveness of a harmful product. Heidelberg: German Cancer Research Center (Ed), 2012.

5 King M. Investor Day — Latin American \& Cánada Region. Lausanne, Switzerland: Philip Morris International.

6 Levy JM. Consumer driven growth. Hampshire, UK: British American Tobacco, 2011

7 MacGuill S. Tobacco control in Chile-an unremarkable market becomes an unlikely bellwether. Euromonitor International, 2013.

8 Moodie C, Ford A, Mackintosh A, et al. Are all cigarettes just the same? Female's perceptions of slim, coloured, aromatized and capsule cigarettes. Health Educ Res 2015;30:1-12.

9 Thrasher JF, Abad-Vivero EN, Moodie C, et al. Cigarette brands with flavour capsules in the filter: trends in use and brand perceptions among smokers in the USA, Mexico and Australia, 2012-2014. Tob Control 2016;25:275-83.

10 Anderson SJ. Marketing of menthol cigarettes and consumer perceptions: a review of tobacco industry documents. Tob Control 2011;20(Suppl 2):ii20-8.

11 Brown JE, Luo W, Isabelle LM, et al. Candy flavorings in tobacco. N Engl J Med 2014:370:2250-2.

12 Klausner K. Menthol cigarettes and smoking initiation: a tobacco industry perspective. Tob Control 2011;20(Suppl 2):ii12-i19.

13 Minaker LM, Ahmed R, Hammond D, et al. Flavored tobacco use among Canadian students in grades 9 through 12: prevalence and patterns from the 2010-2011 Youth Smoking Survey. Prev Chronic Dis 2014;11:E102.

14 Wayne GF, Connolly GN. How cigarette design can affect youth initiation into smoking: Camel cigarettes 1983-93. Tob Control 2002; 11(Suppl 1):132-9.

15 Euromonitor Intenational. New product development in cigarettes: innovate or fail-keeping price in power. Report summary; London: Euromonitor International 2012.

16 KT\&G launches crush-cap ultra-slim. Tobacco Journal International. LT\&G launches crush-cap ultra-slim. Tobacco Journal International 2013. http://www. tobaccojournal.com/KT_G_launches_crush-cap_ultra-slim.51799.0.html

17 Cigarettes in México. Secondary Cigarettes in México 2014. http://www. euromonitor.com/cigarettes-in-mexico/report

18 Pérez-Hernández R, Thrasher JF, Rodríguez-bolaños R, et al. Autorreporte de exposición a publicidad y promoción de tabaco en una cohorte de fumadores mexicanos. Salud Publica Mex 2012;54:204-12.

19 Tobacco Surveillance System TPackSS. Secondary Tobacco Surveillance System TPackSS 2013. http://globaltobaccocontrol.org/tpackss/countries/mexico/

20 Sáenz de Miera Juárez B, Thrasher JF, Reynales Shigematsu LM, et al. Tax, price and cigarette brand preferences: a longitudinal study of adult smokers from the ITC Mexico Survey. Tob Control 2013;23(Suppl 1):i80-5.

21 Saenz-de-Miera B, Thrasher JF, Chaloupka FJ, et al. Self-reported price of cigarettes, consumption and compensatory behaviours in a cohort of Mexican smokers before and after a cigarette tax increase. Tob Control 2010;19:481-7.

22 Ford A, Moodie C, Hastings G. The role of packaging for consumer products: understanding the move towards 'plain' tobacco packaging. Addict Res Theory 2012;20:339-47.

23 Kotnowski K, Hammond D. The impact of cigarette pack shape, size and opening: evidence from tobacco company documents. Addiction 2013;108:1658-68.

24 Moodie C, Angus K, Ford A. The importance of cigarette packaging in a 'dark' market: the 'Silk Cut' experience. Tob Control 2014;23:274-8.

25 Moodie C, Hastings G. Tobacco packaging as promotion. Tob Control 2010;19:168-70

26 Reynales-Shigematsu LM, Rodríguez-Bolaños R, Ortega-Ceballos P, et al. Encuesta de Tabaquismo en Jóvenes. México: Instituto Nacional de Salud Pública, 2011.

27 Braun S, Kollath-Cattano C, Barrientos I, et al. Assessing tobacco marketing receptivity among youth: integrating point of sale marketing, cigarette package branding, and branded merchandise. Tob Control 2016;25:648-55.

28 Dauphinee AL, Doxey JR, Schleicher NC, et al. Racial differences in cigarette brand recognition and impact on youth smoking. BMC Public Health 2013;13:170.
29 Feighery EC, Henriksen L, Wang Y, et al. An evaluation of four measures of adolescents exposure to cigarette marketing in stores. Nicotine Tob Res 2006;8:751-9.

30 Harrell JS, Bangdiwala SI, Deng S, et al. Smoking initiation in youth: the roles of gender, race, socioeconomics, and developmental status. J Adolesc Health 1998;23:271-9.

31 Zhu BP, Liu M, Shelton D, et al. Cigarette smoking and its risk factors among elementary school students in Beijing. Am J Public Health 1996;86:368-75.

32 Goodman E. The role of socioeconomic status gradients in explaining differences in US adolescents' health. Am J Public Health 1999:89:1522-8.

33 Wahl SK, Turner LR, Mermelstein RJ, et al. Adolescents' smoking expectancies: psychometric properties and prediction of behavior change. Nicotine Tob Res 2005;7:613-23.

34 Stephenson MT, Hoyle RH, Palmgreen $\mathrm{P}$, et al. Brief measures of sensation seeking for screening and large-scale surveys. Drug Alcohol Depend 2003;72:279-86.

35 Thrasher JF, Sargent JD, Huang L, et al. Does film smoking promote youth smoking in middle-income countries? A longitudinal study among Mexican adolescents. Cancer Epidemiol Biomarkers Prev 2009:18:3444-50.

36 Pierce JP, Choi WS, Gilpin EA, et al. Validation of susceptibility as a predictor of which adolescents take up smoking in the United States. Health Psychol 1996;15:355-61.

37 Giovino GA, Villanti AC, Mowery PD, et al. Differential trends in cigarette smoking in the USA: is menthol slowing progress? Tob Control 2015;24:28-37.

38 Martini A. Transformation for sustainable growth. Sao Paulo: British American Tobacco, 2009

39 Snook N. Good performance in a challenging environment. Secondary Good performance in a challenging environment 2014. http://www.bat.com/group/sites/ UK__9D9KCY.nsf/vwPagesWebLive/D09Q4LNB?opendocument

40 C. L. Flavor capsule filter: Concept-product test: RJ Reynolds. 2003. http://legacy. library.ucsf.edu/tid/qki06h00; jsessionid=813BBA5B5A5A691B96046B7CFCAE30CF. tobacco04

41 White V, Williams T, Wakefield M. Has the introduction of plain packaging with larger graphic health warnings changed adolescents' perceptions of cigarette packs and brands? Tob Control 2015;24(Suppl 2):ii42-9.

42 Parliament E. Directive 2014/40/EU of the European Parliament and of the Council of 3 April 2014 on the approximation of the laws, regulations and administrative provisions of the Member States concerning the manufacture, presentation and sale of tobacco and related products and repealing Directive 2001/37/EC, 2014. 2014. http://ec.europa.eu/health/tobacco/docs/dir 201440 en.pdf

43 FDA issues orders that will stop further U.S. sale and distribution of four R.J. Reynolds Tobacco Company cigarette products. In: Services. USDoHaH, ed. U.S. Food and Drug Administration, 2015. http://www.fda.gov/NewsEvents/Newsroom/ PressAnnouncements/ucm462407.htm

44 Canadian provinces firsts in world to ban menthol flavour. Frameworl Convention Alliance. Framework Convention on Tobacco Control. http://www.fctc.org/fca-news/ opinion-pieces/1328-canadian-provinces-first-to-ban-menthol-flavouring

45 Elkin L, Thomson G, Wilson N. Connecting world youth with tobacco brands: YouTube and the internet policy vacuum on Web 2.0. Tob Control 2010;19:361-6.

46 Henriksen L. Comprehensive tobacco marketing restrictions: promotion, packaging, price and place. Tob Control 2012;21:147-53.

47 Liang $Y$, Zheng $X$, Zeng $D D$, et al. Exploring how the tobacco industry presents and promotes itself in social media. J Med Internet Res 2015;17:e24.

48 Lovato C, Watts A, Stead LF. Impact of tobacco advertising and promotion on increasing adolescent smoking behaviours. Cochrane Database Syst Rev 2011;(10): CD003439.

49 Wakefield M, Morley C, Horan JK, et al. The cigarette pack as image: new evidence from tobacco industry documents. Tob Control 2002;11(Suppl 1):i73-80.

50 Czoli CD, Hammond D. Cigarette packaging: youth perceptions of "natural" cigarettes, filter references, and contraband tobacco. J Adolesc Health 2014;54:33-9.

51 Morris P. MARKETING INFORMATION SYSTEMS INTL. VIRGINIA SLIMS PACK TEST PRESENTATION. 1992. https://industrydocuments.library.ucsf.edu/tobacco/docs/ $\#$ \#id=pskw0125

52 SEP. Principales cifras del sistema educativo nacional 2013-2014. Secondary Principales cifras del sistema educativo nacional 2013-2014. http://fs.planeacion. sep.gob.mx/estadistica_e_indicadores/principales_cifras/principales_cifras_2013_ 2014_bolsillo.pdf 